\title{
Ritual Art: a Key to the Ancient Egyptian Book of the Dead
}

The Bambara sculpture in fig. 1 is also a ritual object, in fact one of the dramatis personae of a ritual drama. The Civara, as it is called, is carried on the head during the ritual dance as a token of the presence of the mythical antilope which brought agriculture to the Bambara. Besides the male Civara there is also a female one, and in their dance, the two of them dramatize the fertilizing interaction of sun and soil. Without further exploring Bambara ritual, we may notice that a piece of pictorial art is here an integral part of a ritual. It is a mask, carried during the dance and designating its bearer as the mythical antilope.

Also belonging to a ritual are the space and the surroundings in which it is carried out. It is well known how ritual places and temple rooms are often structured and decorated to make out the background and the framework of ritual acts. The place of ritual may be designed as an imago mundi, or it may be chosen or named according to mythical prototypes. Temple rooms may be decorated with mythological and cosmological motifs to identify the ritual acts that take place in them as mythical deeds and cosmologically significant events, exactly as the civara-mask identifies the ritual dance in its mythological and cosmological significance. It is probably in this way that we must understand the pictures of the Last Supper or the Crucifixion often found in Christian churches at the place where the Eucharist is enacted. The picture of Jesus and the twelve is part of the anamnesis: it identifies the ritual meal with its prototype and its foundation. Although the picture is not moved or manipulated during the Eucharist, it would certainly be wrong not to regard it as part of the ritual. The picture of the Crucifixion has a function corresponding to the Agnus Dei and the consecration of bread and wine as the most blessed body and blood of Christ. Both pictures may be omitted since their motifs are represented in the ritual text, but when they are there, they are elements in the ritual drama as well as the corresponding texts. 
In view of the complexity characteristic of ritual, pictures have an immense potential of expression. The many levels and layers of meaning in ritual are often difficult to unite in a single ritual text: The Eucharist is the last meal of Christ, the sacrificial lamb, the glorification of the church in Christ, the forgiving of sins, etc. etc. And the bread is the body of Christ, which is also the church; Christ is also the Word, the creative principle and the gospel of salvation; and the very consecration, in which the host and the wine are said to be the body and the blood of Christ, may be seen as a reenactment of the incarnation. Even more theologies of the Eucharist or ritual layers of meaning might be added. What is not possible in ritual texts and performances, is possible in the ritual picture: to bring all these ritual levels and layers of meaning into the ritual simultaneously. Texts and dramatic performances must of necessity unfold themselves sequentially in time; but the picture may unite everything in a timeless moment.

Illustrations of the many levels of meaning involved in the Eucharist are found most strikingly in the late mediaeval Low German altarpieces. The ritual transsubstantiation of the bread and the wine into the most blessed body and blood of Christ is here given a wealth of meanings and perspectives, which are thus added to the service enacted at the altar. - The altarpiece from Triebsees near Stralsund in fig. 2 is an excellent example: In the middle of the upper register God is shown adored by angels. To the left, primeval sin finds an expression in the image of Adam and Eve in the mouth of Hell, and to the right, the Annunciation of the Virgin Mary is shown. In the middle register, the four evangelists pour the Word of God into a mill driven by the four rivers of Paradise. On both sides, the apostles are seen working the floodgates. In the middle of the lower register, the Word becomes flesh: Christ is shown as a child issuing from the mill and seated in the chalice, which is held by four Fathers of the Church. To the left, the sacrament is distributed, and to the right is shown the coronation of Friedrich III, who was, as the last German emperor, crowned in Rome in 1452. The coronation is thus, as it were, a consequence of the incarnation.

The perspectives and the implications of the altarpiece are thus dramatically represented in the ritual, coefficacious and coenacted in the actual consumption of bread and wine. Whoever partakes of the Lord's supper in Triebsees, participates in the renewal of the incarnation of Christ with all the theological and political implications of the altarpiece.

Among the religions of Antiquity, the religion of ancient Egypt stands out as particularly well known. This is not only due to a wealth of preserved religious texts, but also to an almost incalculable bulk of pictorial represen- 
tations: temple reliefs, tomb paintings, illustrated papyri, etc. And throughout its history of more than two thousand years, ancient Egyptian religion centered on ritual. This means that most often the Sitz im Leben of religious art is ritual. Works of art carry out ritual functions and illustrate ritual practice. Very much like the altarpiece from Triebsees, temple reliefs often add to the dramatic quality of the ritual acts that took place in the temple through representations of the mythical and the topical implications of the ritual. A particularly instructive example is the series of reliefs in the great Ptolemaic temple of Edfu related to the annual celebration of the "Triumph of Horus", i.e. the ritual drama enacting the mythical victory of Horus over Seth, denoting the first beginning of Egyptian kingship and Egypt's perpetual triumph over her enemies. At the end of the series of reliefs, the present king, Ptolemy IX, is declared victorious over the country's enemies.

The extant ritual texts are ample evidence that the ritual was a dramatic performance of the victory of Horus, who is shown on the reliefs harpooning the hippopotamus that represents Seth several times. The killing of the hippopotamus is already known as a theme with symbolic value from prehistoric seals. What we cannot know is how realistic this performance was. Was a hippopotamus, dead or alive, or perhaps a life-size dummy, actually used in the ritual? Or was an ox simply sacrificed, consecrated as Seth $^{2}-$ or was it more like the body of Christ in the Eucharist? Of all the dramatic reliefs in Edfu, fig. 3 is perhaps the one closest to actual ritual practice. The accompanying text explains that a butcher, i.e. a sacrificial priest, is cutting up a cake hippopotamus which is then divided between the gods participating in the ritual. At the same time, a lector priest is reading a spell of annihilation to Seth. - The dramatic ritual scenes, however, represent a more radical mythological realism. The first part of the drama is dominated by scenes like fig 4 , showing the king in a gesture of adoration before the mythological representation of Horus harpooning the hippopotamus. With only minor variations, this theme is repeated in the first five scenes, a redundancy no doubt denoting the rhythm and the extension in time of the ritual. The mythological realism of these scenes may, however, be viewed very much like Jesus in the chalice on the Triebseeser altarpiece: the picture adds to the dramatic quality of the ritual. It is an extension of the ritual assertion, or we might say a mythological transfiguration of the ritual actually performed. The representation of the king in a

\footnotetext{
${ }^{1}$ Fairman 1974, cf. Podemann Sørensen 1986.

${ }^{2}$ Cf. Pyr. Spruch 580.
} 
posture of adoration would thus, in a general way, represent the ritual as in fact it does in countless ritual scenes in Egyptian temples. The mythological part of the relief should then be taken not as a documentary account of what was in fact performed, but as the transsubstantiation of whatever was performed. - And as a further analogy of the Triebseeser altarpiece, the results of the ritual are also part of the dramatic series of reliefs in Edfu. Horus' mythical victory over Seth is, as we have already pointed out, the exemplar and archetype of pharaoh defeating the enemies of Egypt. The victorious king defeating the enemies is the motif dominating the pylons of New Kingdom temples, very much like Heracles defeating monsters or lapiths fighting centaurs decorate the facades of Greek temples and serve to delimit the cosmos of the temple against the chaos surrounding it. Towards the end of the Edfu series of reliefs is seen an unusual variation of this motif, juxtaposed with its mythical exemplar, Horus harpooning the hippopotamus (fig. 5). The relief shows the king harpooning a captive enemy and, symmetrically arranged, the mythological scene. The captive enemy denotes, as it were, the topical implications or the results of the ritual, just as the Triebseeser altarpiece represents the imperial coronation as a worldly reflection of the incarnation, analogous with the transubstantiation that takes place in the ritual. In the Edfu reliefs, it is important to notice that the king, who was formerly represented in the rather undramatic posture of adoration, is now drawn into the dramatic part of the picture. This is another variety of what we have called the pictorial transsubstantiation of ritual: the officiating ritual person who did, in the ritual actually performed, perhaps nothing but recite a text, may be represented as taking part in the drama, more or less integrated in its mythological framework.

The idea of a 'pictorial transsubstantiation of ritual' may serve as a key to understanding the sequence of pictures in illustrated versions of the Egyptian Book of the Dead. ${ }^{3}$ As is well known, the Book of the Dead has been interpreted in a number of different ways, which are by no means easily reconciled or united by some common purport. Part of its content seems to be pictures and verbal accounts of the beyond, and some have therefore

\footnotetext{
${ }^{3}$ The text of the New Kingdom Book of the Dead with illustrations and variants is edited by Naville 1886 and translated by Hornung 1979, by Barguet 1967. A facsimile edition, including the papyrus of Hunefer, is Budge 1899. The translation by Faulkner 1989 has a wealth of photographic reproductions of the illustrations. Colour reproductions of all illustrations in the papyrus of Hunefer are most easily accesible in Rossiter 1979.
} 
taken it to be a kind of guide-book, which the deceased would somehow consult during his journey in the hereafter. Others have regarded it more like a passport giving access to a blessed life in the beyond, and in fact, some of its texts might be read as certificates or letters of introduction. Still others have noticed that the Book of the Dead has abbreviated versions of some of the rituals that are known to be part of the funeral and the mortuary ritual, e.g. the Ritual of Opening the Mouth and the Ritual of Embalming. As part of the funerary equipment, the book might thus be a representation of these rituals, meant to perpetuate them for the benefit of the deceased.

There is, however, one part of the content of the Book of the Dead that was never fully taken into account in the attempts to understand its religious function or 'Sitz im Tode': the many representations of temple ritual or culte divin, as opposed to mortuary ritual, both in its texts and its illustrations. We shall deal only with the latter.

A rapid survey of the famous New Kingdom illustrated Book of the Dead counts 20 representations of the deceased in a posture of adoration in the papyrus of Ani, 9 in each of the lesser papyri of Hunefer and Anhai, and only 4 in the highly stylized papyrus of Maherpa. It is thus a quite prominent feature that must be taken into account when considering the religious function of the Book of the Dead. And this is where our new-struck dogma of pictorial transsubstantiation may serve as a key to understanding the role of illustration in the Book of the Dead.

The classical illustrated New Kingdom Book of the Dead does in fact begin with a representation of the deceased in a posture of adoration, followed by a hymn to Re-Harakhte, the rising sun (fig. 6). In the papyrus of Hunefer which, for the sake of brevity, will serve us as a specimen, the hymn is followed by a quite peculiar compact picture, originally taken to be an independent, purely pictographic chapter of the Book of the Dead. It does not, as might be imagined, represent strange beings and features of the beyond, but the rising sun to whom the hymn is addressed. ReHarakhte is shown as a falcon with a sun-disk on his head, worshipped by the heavenly baboons as he rises. We are thus facing the transsubstantiation of the hymn - or the heavenly transfiguration of the worship of Hunefer and his wife: The baboons are worshipping the Sun-god with the same conventional gesture as shown in the picture of the deceased and his consort. Their worship of the Sun-god, the hymn, is thus, as it were, conveyed to the heavenly baboons. The lower part of the picture is another dramatic transfiguration of their worship: The resuscitation of Osiris. Osiris is depicted as the so-called Djed-pillar, a ritual object about which we know 
little more than the fact that it represents Osiris. The god is flanked by his two sisters Isis and Nephthys, each with just a short sentence of the elaborate lamentations which in the well-known ritual restore Osiris to life in order that he may beget an heir to the throne. A proper ritual text with these lamentations and directions for their use is not extant before about $312 \mathrm{BC}$, but the motif occurs very often throughout the New Kingdom (1552-1069). Throughout this period, the Sun-god and Osiris are seen very much as two aspects of the same god, and the sunrise and the resuscitation of Osiris are both important - and interchangeable - expressions of the Egyptian idea of regeneration. The two motifs may even be combined or mixed, as is seen in a number of paintings at the entrance of late New Kingdom royal tombs, where Isis and Nephthys serve as midwives of the rising sun.

What, however, has all this to do with Hunefer and the 'Sitz im Tode' of the Book of the Dead? The answer is rather evident: Through his hymn and its ritual transfigurations or transsubstantiations, Hunefer - or Osiris Hunefer, as he is conventionally called in his Book of the Dead - participates in regeneration. The resuscitation of Osiris is also his resuscitation, and the rising of the sun from the darkness of the night and from the Netherworld is also the rising of his life from death. I hasten to add that in the Egypt of the New Kingdom this implies no idea of an individual resurrection. We are in Africa, and the deceased ancestors are the source of life of their descendants.

In the papyrus of Hunefer there follows once more the picture of Hunefer and his wife in a posture of adoration, this time with a hymn to Osiris (fig. 7). This sequence is thus elegantly symmetrical with the preceding combination of solar and Osirian elements. In pursuing our theme of pictorial transsubstantiation, it is important to note the following picture of Thoth, carrying the ankh- and was-signs ('life' and 'dominion') to Osiris in the manner of an offering. Thoth is the god most often depicted in priestly or ritual roles and may - to put it in the briefest possible way - be considered the priest among the gods. In the present context, his role is analogous to that of the heavenly baboons in the preceding picture. The hymn to Osiris is transsubstantiated in Thoth carrying life and dominion to Osiris.

Then follows the famous scene of the weighing of the heart of the deceased, the favourite picture of all handbook surveys of ancient Egyptian religion (fig 8). The weighing of the heart itself is not easily understood as a transfiguration of Hunefer's worship; it is preceded, however, by the scene in the upper register, where Hunefer is seen worshipping an extended Ennead of gods. In this way the motif of the deceased in a posture 


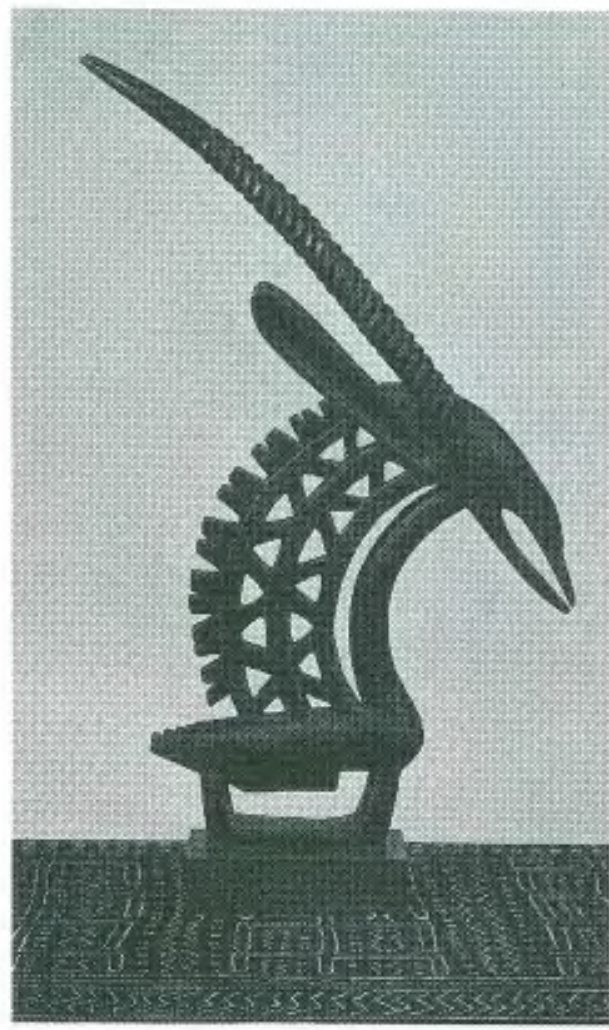

Fig. 1. Leuzinger s.a., Pl. 5 (From the private collection of Elsy Leuzinger).

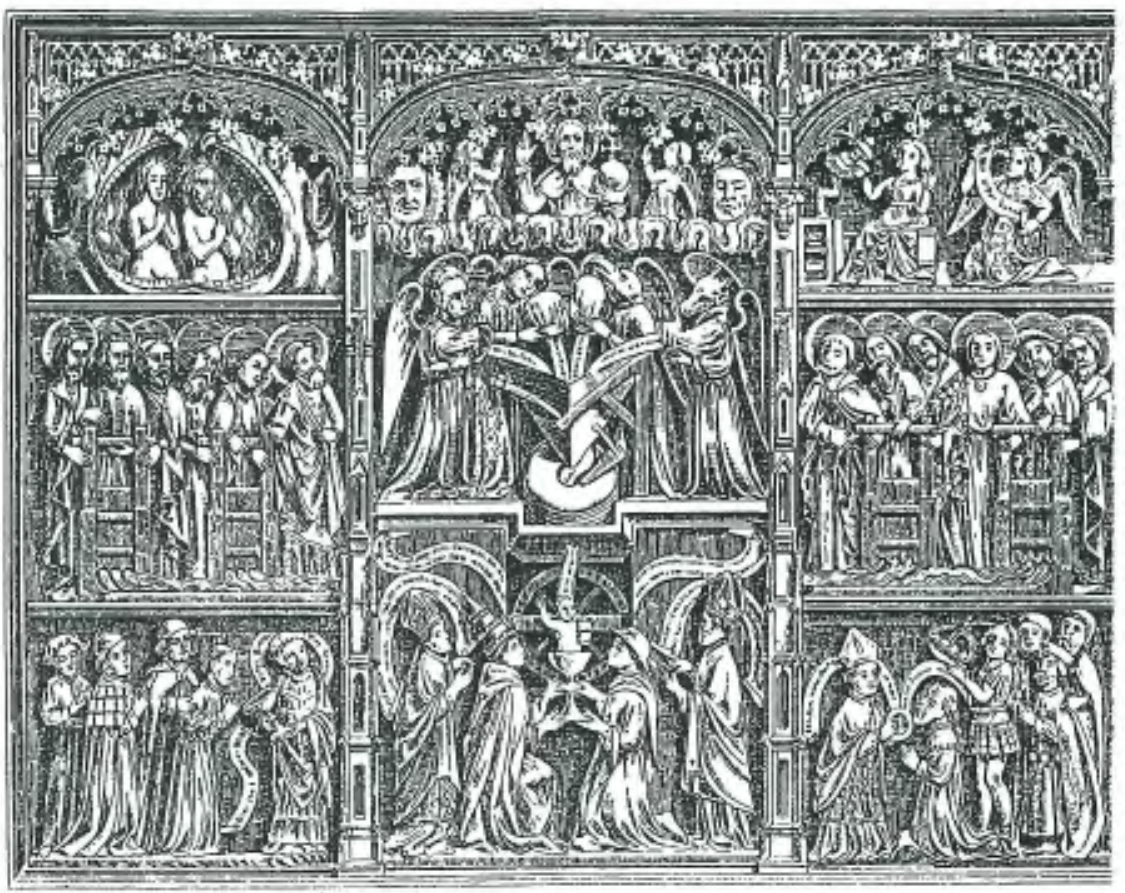

Fig. 2. Molsdorf 1984, Tafel 10. 

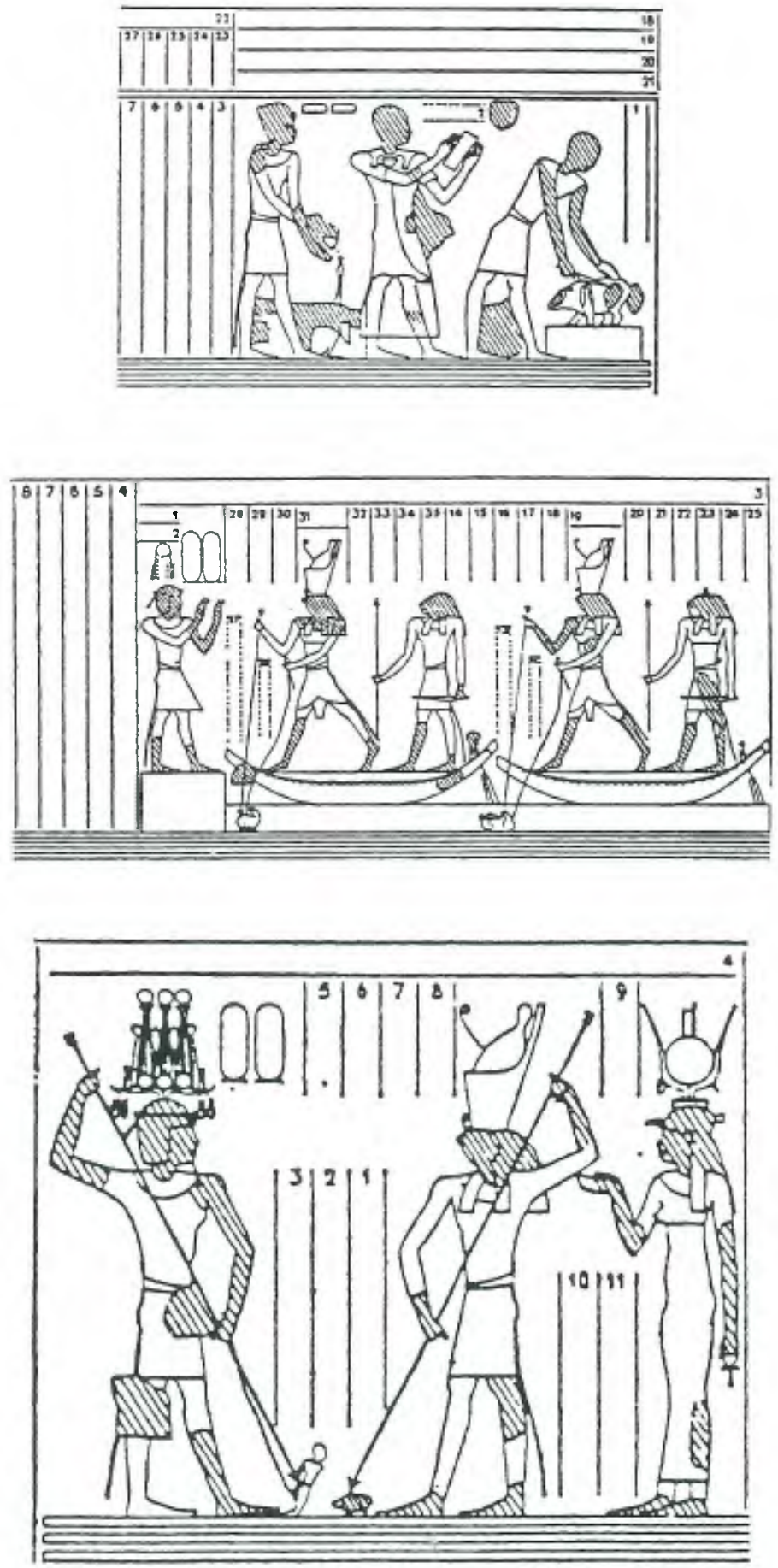

Fig. 3-5. Fairman 1974, pp. 113, 94, 111. 


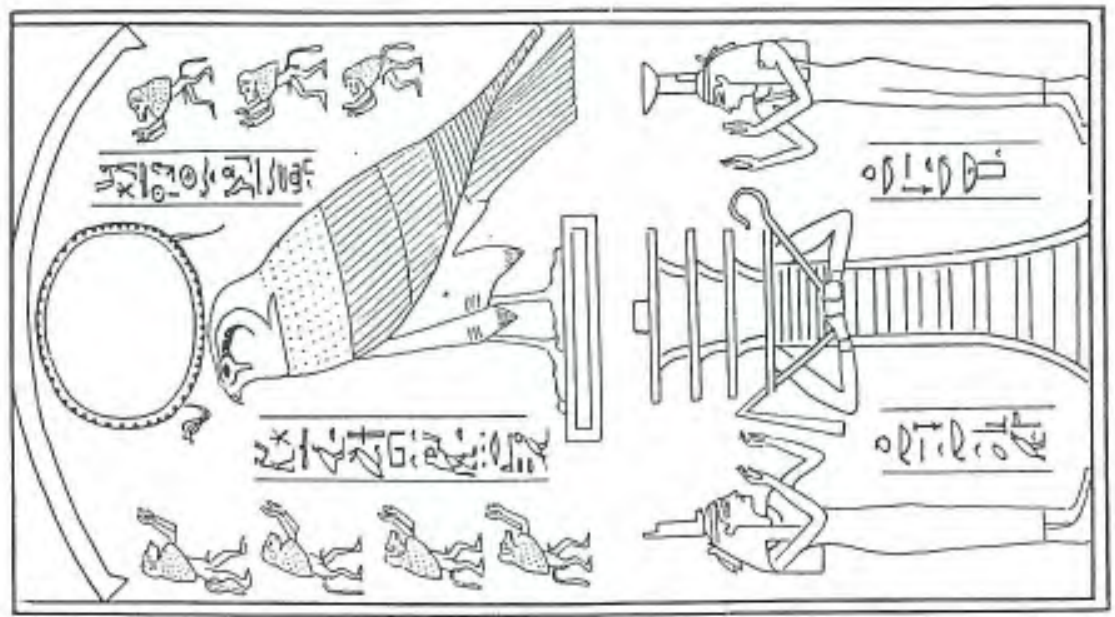

MU

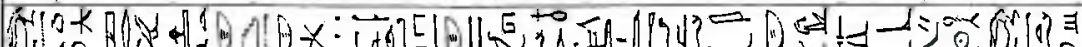
4h 100 T1/ll-

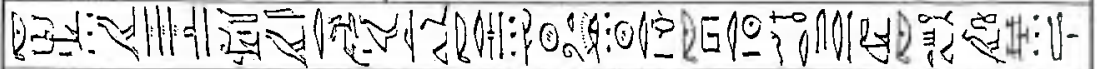

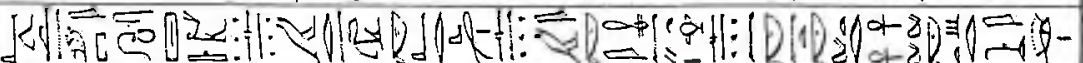
M ne $=N c_{-3}$

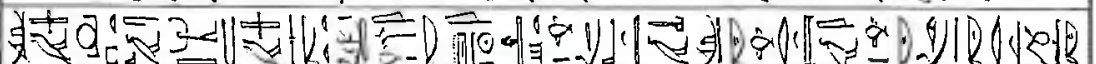
H(A S 1. $\Rightarrow$ ind of

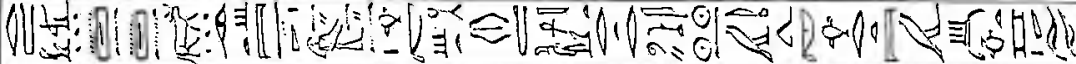

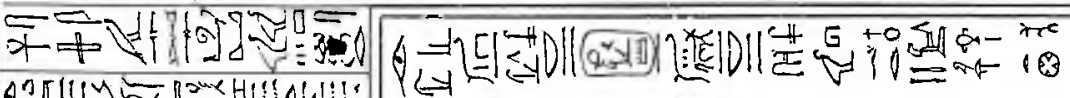

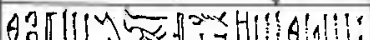
?Dllibard

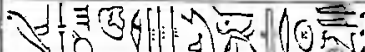
Nio-illid

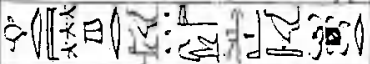

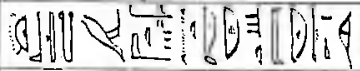

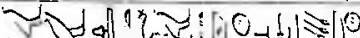

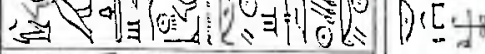

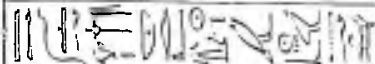

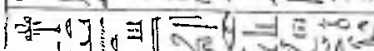
- did al DE

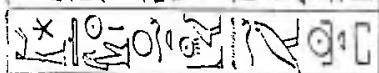

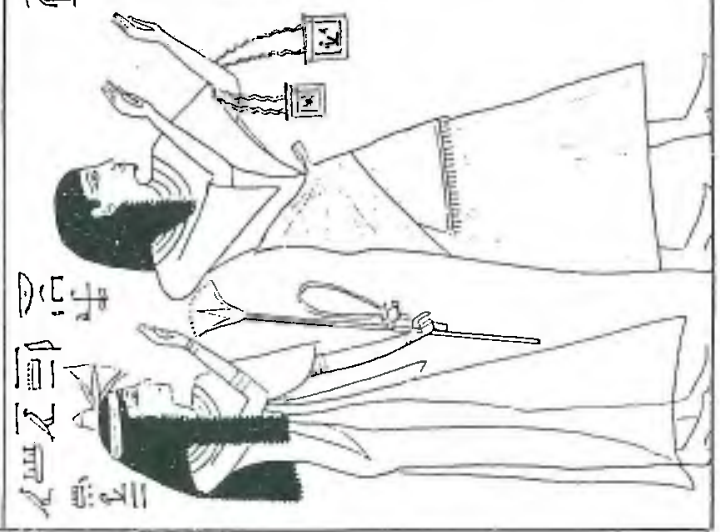




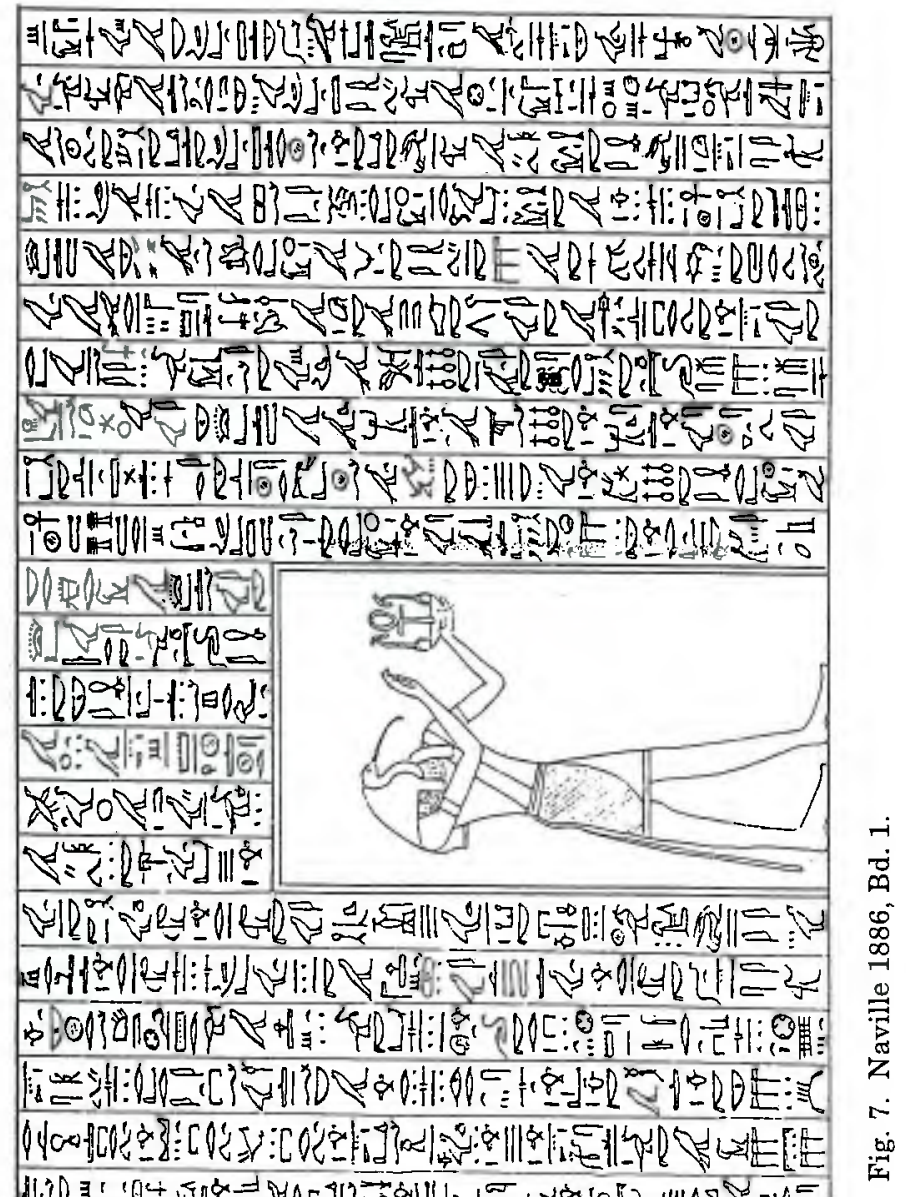




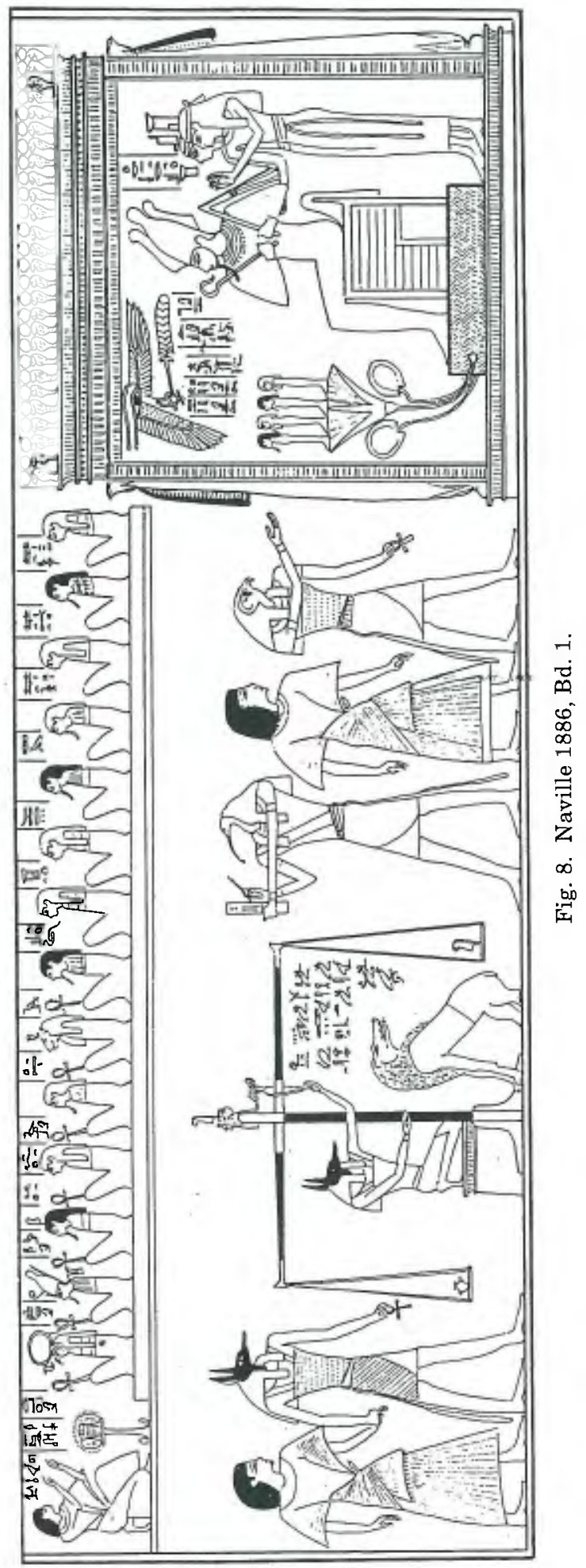




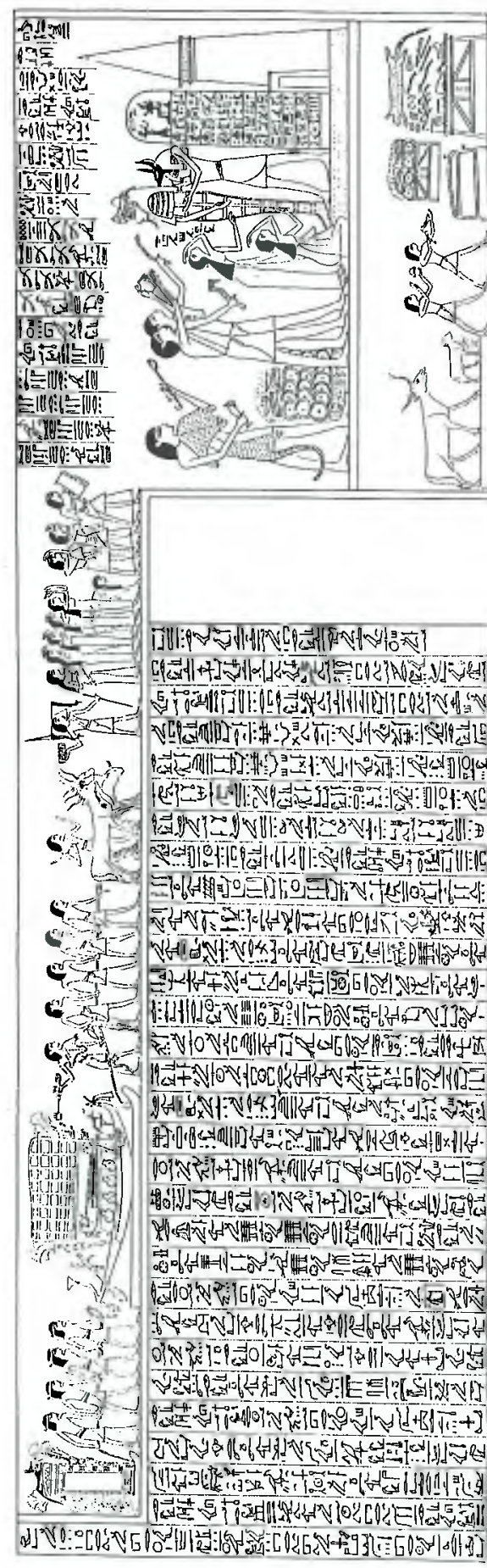




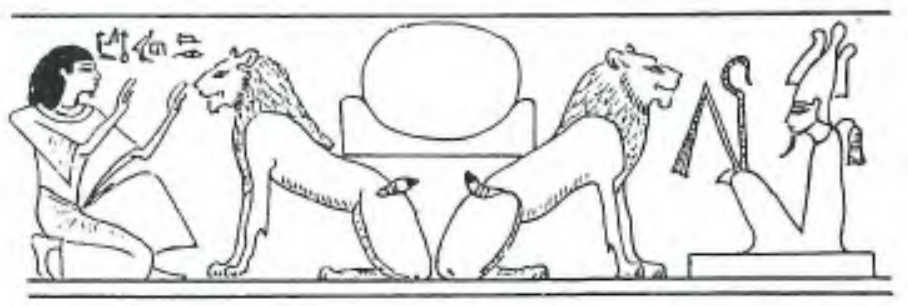

Fig. 10. Naville 1886, Bd. 1.

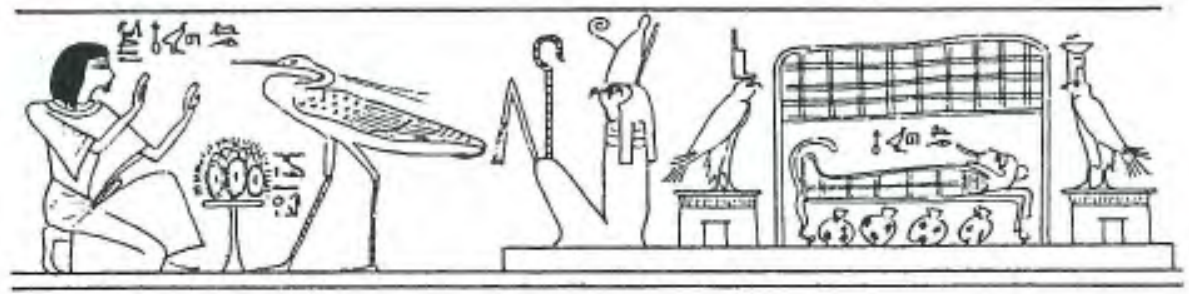

Fig. 11. Naville 1886, Bd. 1. 


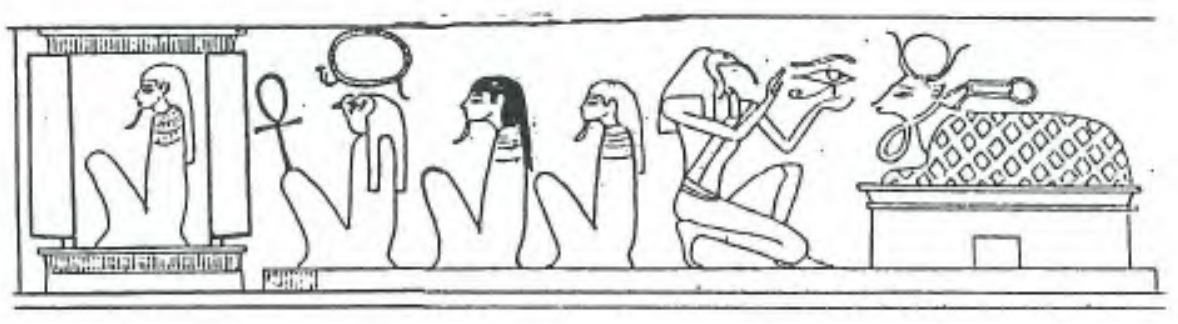

Fig. 12. Naville 1886, Bd. 1.

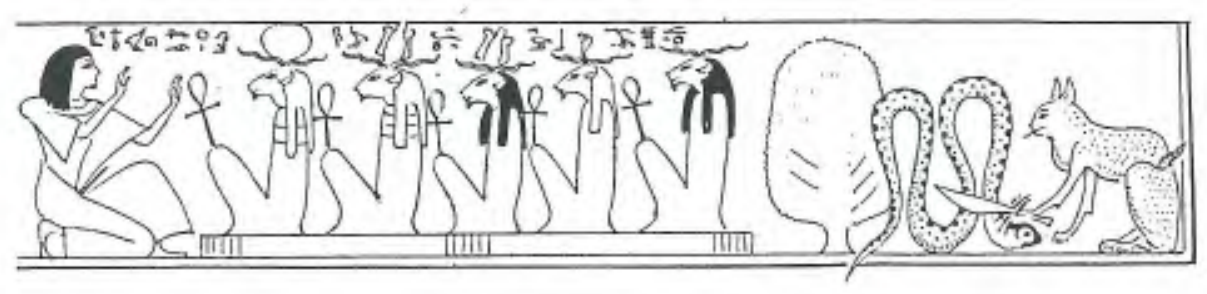

Fig. 13. Naville 1886, Bd. 1.

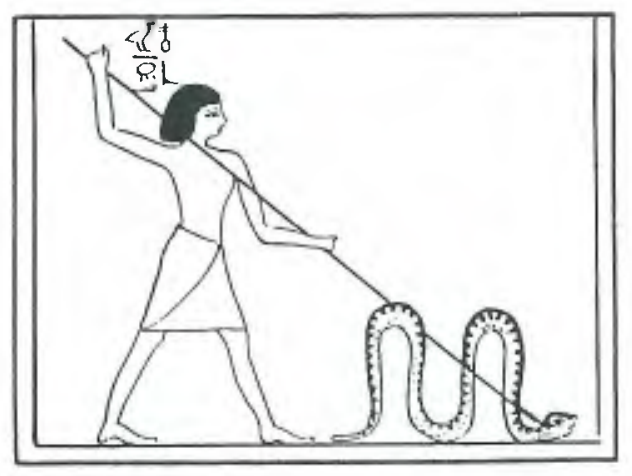

Fig. 14. Naville 1886, Bd. 1. 
of adoration is, as it were, kept alive; but its relation with the following scenes of the weighing of the heart and the introduction of the deceased before Osiris is clearly different from what we found in the previous sections. If these scenes may somehow reflect ritual ${ }^{4}$, Hunefer is now the object of ritual and no longer the officiating person. - This is also the case in the following scenes (fig. 9) showing the funeral procession and the opening of the mouth performed on the mummy of the deceased. Such representations of funeral and mortuary ritual have their own raison d'être in the Book of the Dead and need not concern us here.

In the rest of the papyrus, however, Hunefer in a posture of adoration is invariably the introductory figure in the different scenes: We find him (in fig. 10) adoring the two lions with the rising sun; they are called 'yesterday' and 'tomorrow', and according to the explanation found in the text (Ch. 17), this means Osiris and Re, the two gods in whom the deceased already ritually participates. It is important to note that he is not just adoring one or two cult statues; what is shown is, as we found in fig. 6 , a sunrise, i.e. a transfiguration of his worship, not its object. The papyrus of Hunefer, insisting on the parallelism of solar and Osirian regeneration, adds an Osiris figure to the scene. Thus understood, the picture is a mythical and dramatic transsubstantiation of the worship perpetuated in the figure of Hunefer with his arms raised in adoration. It serves to make him participate in Osiris and Re, the complementary expression of regeneration, as well as the primeval, exemplar sunrise.

The parallelism of solar and Osirian symbolism is also retained in the next picture (fig. 11), in which Hunefer is depicted in the usual posture of adoration in front of a Benu-bird or Phoenix. The bird is called "the $b a$ of Re", and the Phoenix is in fact intimately connected with the Sun-god. Its mythology is extremely varied, but in the present context of the Book of the Dead it is safe to regard it as a symbol of renewal and regeneration (cf. Kakosy 1982: 1030-1039). In the second half of the sequence follows the Osirian counterpart: Behind a hawk-headed god, perhaps Sokar or Osiris-

\footnotetext{
${ }^{4}$ No full discussion of this problem is possible within the scope of this article. The scenes have a complicated text history within the tradition of the Book of the Dead and seem to reflect elements of temple ritual in a not very conspicuous way. The introduction of the deceased before Osiris reflects priestly initiation; the text above the scene uses the verb $b s j$, the normal term for initiating priests, cf. Kruchten 1989: 147-204. The weighing of the heart is often, although not in the paryrus of Hunefer, the illustration of chapter 125 of the Book of the Dead with the famous 'negative confession' or 'declaration of innocence', which is, according to Merkelbach 1968 , originally a priestly oath.
} 
Sokar, is a bier flanked by 'the two kites', a shape sometimes assumed by Isis and Nephthys bewailing Osiris. On the bier, in the place of Osiris, who is to be resuscitated by the lamentations of his two sisters, lies the mummy of Osiris-Hunefer. Through his worship, dramatically transsubstantiated into these scenes, Hunefer participates in the self-regenerating capacity of the Phoenix and the regeneration of Osiris.

A little later on in the papyrus of Hunefer, we find him and his wife in a posture of adoration very much like the first picture of the papyrus. In front of them is the continuation of chapter 17 of the Book of the Dead. In the upper register, above the text and in front of Hunefer and his wife, is our fig. 12 with a row of gods, the first one sitting in a gateway or a chapel with open doors. This is generally interpreted as the entrance to the beyond, and Hunefer, or the text just above his arms raised in adoration, does in fact invoke the "Lords of the West, the Ennead which is in the necropolis". "The gate of the Netherworld" is also one of the meanings attached to it by the text of chapter 17, and at the end of the row of gods, the cow Mehet-Weret is lying on a tomb-like structure. In illustrated Books of the Dead, she is very often found at the Western Mountain, marking the entrance to the beyond. A purely topographical interpretation, like "Hunefer and his wife have now arrived at the entrance to the beyond ...", would, however, be much too narrow, and it would raise questions as to where they were in the earlier part of the sequence. Chapter 17 has two other interpretations of the gate: "the gate of what Shu lifted/lifts up (stsw Šw)", i.e. the gate of the sky or perhaps the gate through which Shu lifts the Sungod out of the Netherworld, and "the door through which my father Atum goes, when he goes to the eastern horizon of the sky". Both these interpretations may somehow denote the door of the other world, but their emphasis is on creation and renewal: the lifting of Shu, the Sun-god proceeding towards the eastern horizon. This is also what fits the sequence of illustrations as a whole: the gate or chapel is the gateway of regeneration, and its meaning is not limited to the topography of the beyond. In fact, every Egyptian sanctuary or naos may be regarded as the door of Netherworld and Heaven simultaneously ${ }^{5}$, and certainly as the gateway of renewal and regeneration.

The cow Mehet Weret is a bearer of similar or parallel meanings. In the text of chapter 17 she is said to have born the Sun-god, and there are allusions to Thoth healing the eye of the Sun-god and bringing it back to him. The web of meanings attached to Mehet Weret and the eye of Re is ex-

\footnotetext{
${ }^{5}$ Cf. the daily temple liturgy P. Berlin 3055, col. 4, 3-4, cf. Moret 1902.
} 
tremely complicated, but their general significance is, I believe, clear enough: the eye of the Sun-god (i.e. the sun) is restored, the Sun-god is born, and we are once more dealing with sunrise and mythological exemplars of regeneration. And, once again, Hunefer participates in this mythological imagery of regeneration through his worship. The figure of Thoth with the eye - the eye of Horus as the conventional symbol of offerings or the eye of Re according to the myth cited in chapter 17 - serves to connect the worship of Hunefer with its pictorial and mythical transsubstantiations. It is both part of the myth and analogous with the similar figure of Thoth bringing life and dominion to Osiris in the second scene of the papyrus (fig. 7).

The last scene in Hunefer's papyrus (fig. 13) shows him once more in a posture of adoration. The gods in front of him are Re, Shu, Tefnut, Geb, and the Ram of Mendes, and the dramatic episode illustrated at the very end is, still according to chapter 17 of the Book of the Dead, the destruction of the enemies of the Sun-god in Heliopolis on the day after the night in which the Ished-tree was split. These mythological episodes are known only from allusions. The Ished or sacred persea tree has a number of functions, and the recurring mythical allusions that it was split are rather enigmatic. The most convincing interpretation is the one offered by P. Barguet (1967: 61, n. 35), that it denotes the sky-goddess Nut, who was split open at the birth of the Sun-god. This nocturnal and critical delivery is then parallelled by another critical victory: the destruction of the enemies. In the picture this has been reduced to the cat cutting off the head of a serpent, probably Apophis, the exemplar enemy of Re who threatens the passage of the solar boat through both sky and netherworld. Apophis is the embodiment of the crisis that must be overcome to keep the sun on its regular course and to secure the regenerative rhythm of nature. This is what the mythological cat does with a quick cut of the knife, and it is also what Hunefer does through the pictorial transsubstantiation of his worship. In the text of chapter 17 , he does in fact identify himself as this mythological cat, which is also said to be Re himself.

There was a temple ritual to overthrow Apophis. The full text of this ritual, "performed every day in the temple of Amun-Re at Karnak", is extant only in a papyrus of the time of Alexander the Great. ${ }^{6}$ Some of the longer and more elaborate New Kingdom Books of the Dead have excerpts from this ritual, which count as chapter 39 of the Book of the Dead. The illustrations of this chapter regularly represent the deceased himself spearing

\footnotetext{
${ }^{6}$ P. Bremner Rhind 22, 1-32, 12, cf. Faulkner 1933.
} 
Apophis (fig. 14). The ritual person may thus, as we have seen with the king in the Edfu reliefs (fig. 5), be drawn into the dramatic representation which is, in fact, nothing but the pictorial transsubstantiation of what he recites.

It is, however, exactly the recurring modest picture of Hunefer - and other possessors of funerary papyri - in a posture of adoration that provides the key to understanding the religious function of the ancient Egyptian Book of the Dead. Like the very similar figures on votive stelae, these pictures serve to perpetuate the worship or the culte divin of the deceased. In the New Kingdom Books of the Dead, this perpetuation of culte divin in text and illustrations is the very point of departure.

The idea of 'pictorial transsubstantiation' also known from temple ritual has further enabled us to describe how illustrated Books of the Dead work their way from this point of departure into something relevant in the funerary context of the book. We have seen that all the mythological transfigurations of Hunefer's worship serve the principles of solar and Osirian regeneration: the sunrise, the mythical birth of the Sun-god, the overthrowing of Apophis, the resuscitation of Osiris. By perpetuating his worship and its transsubstantiations, the book serves to render its possessor primeval and to make him participate in the regenerative rhythm of nature, that will secure his continued existence as a source of life for his kin.

\section{References Cited}

\section{Barguet, Paul}

1967 Le Livre des Morts des anciens égyptiens. Paris: Cerf. (Litteratures anciennes du Proche-Orient, 1)

Budge, E. A. Wallis

1899 The Book of the Dead. Facsimiles of the papyri of Hunefer, Anhai, Kerasher and Nechemet. (Imp.-fol.). London: British Museum.

Fairman, H. W

1974 The Triumph of Horus. An Ancient Egyptian Sacred Drama. London: Batsford.

Faulkner, Raymond 0 .

1933 The Papyrus Bremner-Rhind. Bruxelles: Fondation égyptologique Reine Élisabeth. (Bibliotheca Aegyptiaca, 3)

1989 The Ancient Egyptian Book of the Dead. London: British Museum Publications.

Hornung, Erik

1979 Das Totenbuch der Ägypter. Zürich: Artemis Verlag. 


\section{Kakosy, Lazlo}

1982 Phoenix. In: Wolfgang Helck and Wolfhart Westendorf (Hrsg.), Lexikon der Ägyptologie; Bd. 4; pp. 1030-1039. Wiesbaden: O. Harrasowitz.

Kruchten, Jean-Mari

1989 Les annales des pretres de Karnak (XXI-XXIIImes dynasties) et autres testes contemporains relatifs a l'initiation des pretres d'Amon. Leuven: Departement orientalistik. (Orientalia Lovaniensia analecta, 32)

Leuzinger, Elsy

s. a. Afrika. Negerfolkenes Kunst. København: Hassing.

Merkelbach, $\mathbf{R}$.

1968 Ein ägyptischer Priestereid. Zeitschrift für Papyrologie und Epigraphik 2: 7-30.

Molsdorf, Wilhelm

1984 Christliche Symbolik der Mittelalterlichen Kunst. Graz: Akademische Druck- und Verlagsanstalt. [1926]

Moret, Alexandre

1902 Le rituel du culte divin journalier en Égypte. Paris: Librairie Ernest Leroux. (Annales du Musee Guimet. Bibliotheque d'étude, 14)

Naville, Edouard

1886 Das Aegyptische Todtenbuch der XVIII. bis XX. Dynastie aus verschiedenen Urkunden zusammengestellt. 2 Bd. Berlin: Asher.

Podemann Sørensen, J.

1986 Three Varieties of Ritual Drama. Temenos 22: 79-92.

Rossiter, Evelyn

1979 The Book of the Dead. Papyri of Ani, Hunefer, Anhai. Genève: Editions Minerva. 